\title{
Nutritional condition of female Calanus euxinus from cyclonic and anticyclonic regions of the Black Sea
}

\author{
Tatyana V. Yuneva ${ }^{1}$, Leonid S. Svetlichny ${ }^{1}$, Oleg A. Yunev ${ }^{1}$, Zinaida A. Romanova ${ }^{1}$, \\ Ahmet E. Kideys ${ }^{2}$, Ferit Bingel ${ }^{2}$, Zahit Uysal ${ }^{2}$, Aysen Yilmaz ${ }^{2}$, Georgy E. Shulman ${ }^{1, *}$
}

${ }^{1}$ Institute of Biology of the Southern Seas, National Academy of the Sciences of Ukraine, Nakhimov Av. 2, Sevastopol 335011, Ukraine

${ }^{2}$ Middle East Technical University, Institute of Marine Sciences, PO Box 28, 33731 Erdemli, Içel, Turkey

\begin{abstract}
The content and composition of lipids in Calanus euxinus females were studied in cyclonic and anticyclonic regions in the southern Black Sea during the period of persistent density stratification (September 1996). The lipid content of $C$. euxinus from cyclonic regions was greater than of individuals from anticyclonic regions (average 101.9 and $58.8 \mu \mathrm{g}$ ind. $^{-1}$, respectively). Total lipid content (mainly wax esters, 70 to $72 \%$, and triacylglycerols, 8 to $13 \%$ ) of female C. euxinus was correlated with chlorophyll a (chl a) (mean integrated concentration) $(\mathrm{r}=0.92, \mathrm{p}<0.005)$. The high correlation with chl a was shown also for wax ester content, used as a long-term index of food supply $(r=0.89, p<0.05)$. The correlation between triacylglycerol content (a short-term index) and chl a was not significant $(\mathrm{r}=$ $0.66, \mathrm{p}<0.2$ ). In cyclonic regions the mean integrated chl a concentration $\left(0.38 \mathrm{mg} \mathrm{m}^{-3}\right.$ ) (as an indicator of phytoplankton food biomass) was 1.7 -fold higher than in anticyclonic areas. The same trend occurred for mean integrated concentrations of nitrate and phosphate 10.996 and $0.299 \mu \mathrm{M}$ in cyclonic and 0.438 and $0.061 \mu \mathrm{M}$ in anticyclonic regions, respectively) in the chl a containing layer. Thus, conditions for total primary productivity in cyclonic regions were more favorable than in anticyclonic ones. This was consistent with lipid levels in female C. euxinus.
\end{abstract}

KEY WORDS: Calanus euxinus - Black Sea · Food supply · Lipids - Wax esters · Triacylglycerols Chlorophyll $\cdot$ Cyclonic regions $\cdot$ Anticyclonic regions

\section{INTRODUCTION}

Calanus euxinus is one of the most important copepods of the offshore pelagic food chain of the Black Sea (Vinogradov et al. 1992b); it is a link between phytoplankton and many species of fish, including commercially important ones. Over the last decade, the abundance of $C$. euxinus has declined appreciably (Vinogradov et al. 1992b, Kovalev et al. 1998). This may be associated with the predation impact of the recently introduced ctenophore Mnemiopsis leidyi (Anninsky et al. 1998) and/or with changes in food (i.e. phytoplankton) composition due to pollution (Vinogradov et al. 1992b) or simply with climatic changes (Kovalev et al. 1998, Niermann et al. 1999).

•Addressee for correspondence. E-mail: shulman@ibss.iuf.net
In the estimation of the nutritional condition (or food provision) of marine animals in the natural environment, physiological and biochemical indices are widely used. They involve, for example, determinations of in situ feeding rates (measured by means of gut fullness and the degree of fluorescence in the gut from ingested phytoplankton pigments; Hayward 1980, Cox et al. 1983, Båmstedt et al. 1990, Bautista et al. 1992, Besiktepe et al. 1998), of digestive enzyme activity (Cox et al. 1983, Bamstedt \& Ervik 1984), of growth rate using the ratio between RNA and DNA content (Ota \& Landry 1984), and of egg production rate and fecundity (Marshall \& Orr 1972, Hirche et al. 1991, Mullin 1991, Peterson et al. 1991). However, most of these methods are often difficult to use in field investigations and they are not always free from the effects of animal capture and other experimental procedures. 
A very reliable and less cumbersome indicator of the nutritional condition of Calanus spp. is body lipid content (Håkanson 1984, 1987, Sargent \& Henderson 1986, Bamstedt et al. 1990). The level of lipid accumulation of Calanus has been shown under laboratory conditions to depend on the concentration and composition of the phytoplankton consumed (Lee et al. 1970 , 1971, Sargent et al. 1977, Håkanson 1984). The class of storage lipid is important in characterising the copepods' nutritional state. Wax ester content is a measure of the animal's long-term nutritional history, whereas the triacylglycerol content may reflect its recent feeding history (Sargent et al. 1977, Håkanson 1984). The turnover of triacylglycerol occurs faster than wax esters. For example, the triacylglycerol content of late copepodites of $C$. pacificus reached a maximum over a few hours from the onset of feeding in the laboratory (Håkanson 1984). Much more time (weeks at high food concentrations) was required for maximum wax ester accumulation. Similar temporary ratios were shown for mobilisation of these substances in conditions of food shortage (Lee \& Barnes 1975, Sargent et al. 1977 , Håkanson 1984).

Temporal variability in feeding conditions (e.g. biomass of phytoplankton) influence lipid storage in Calanus spp. For example, the highest lipid (mainly wax ester) content in higher copepodite stages of $C$. fin-

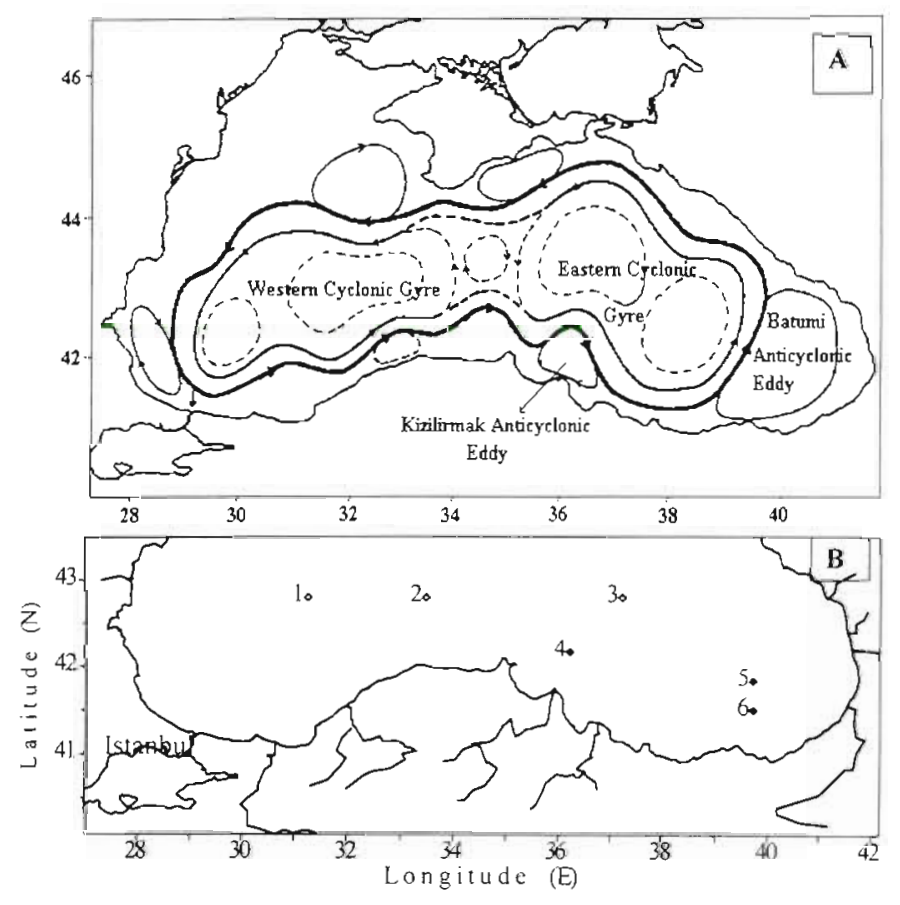

Fig. 1. (A) General circulation of surface currents in the Black Sea (modified from Oguz et al. 1993). (B) Location of sampling stations. (0) Stations in cyclonic zone, $(\bullet)$ stations in anticyclonic zones marchicus and $C$. helgolandicus are known to coincide with the spring phytoplankton bloom at high latitudes (Marshall \& Orr 1972, Gatten et al. 1979, 1980). Wax esters formed in periods of abundant food (i.e. spring and summer) are then utilised for energy expenditure and subsequently gonad formation during the diapausing period in winter, when these copepods are not feeding (Sargent \& Falk-Peterson 1988).

The spatial variability in the lipid content of Calanus spp. is also related to the differences in food supply. Previously, we showed such variability for total lipid, wax ester and triacylglycerol contents of migrating Stage $\mathrm{V}$ copepodites and females of $C$. euxinus, sampled from different regions of the northern Black Sea (Yuneva et al. 1997). The lipid content of similar-sized females varied by 3 - to 4 -fold, and correlated with both the biomass of phytoplankton (10 to $50 \mu \mathrm{m})(\mathrm{r}=0.82$, $\mathrm{p}<0.005$ ) and chlorophyll a (chl a) concentration (integrated over $75 \mathrm{~m})(\mathrm{r}=0.84, \mathrm{p}<0.005)$. Similar relationships were obtained for C. pacificus in the California Current and off San Diego (Håkanson 1987).

In some instances there is no strong correlation between the lipid content of Calanus spp. and indicators of phytoplankton biomass (Ohman 1988, Bamstedt et al. 1990, Willason et al. 1993). It has been argued that other potential food organisms such as bacteria, ciliates and detritus may have been underrated in these cases (Petipa 1981, Fessenden \& Cowles 1994. Ohman \& Runge 1994). The correlation may also be low where copepods feed on small phytoplankton patches, which could often be overlooked during routine measurements (Dagg 1977). Additionally, competition may decrease the amount of food accessible to copepods and therefore may influence their lipid accumulation (Raymont 1976, Parsons et al. 1984).

The Black Sea, due to its very limited water exchange with neighbouring seas, is the largest anoxic water body of the world. Only about $13 \%$ of its waters contain oxygen, and aerobic life is absent below 100 or $200 \mathrm{~m}$. The main circulation characteristics of the Black Sea are the presence of a Rim Current and 2 separate cyclonic gyres occupying the western and eastern halves of the basin (Oguz et al. 1993; Fig. 1.A). There are also a few permanent anticyclonic eddies (e.g. Batumi and Kizilirmak) in the southern Black Sea. The centres of the cyclonic gyres are upwelling regions, whilst those of the anticyclonic eddies show downwelling characteristics. The relatively limited number of species (Vinogradov et al. $1992 \mathrm{~b}$ ) and well-defined hydrological regime of the Black Sea seem to provide a convenient system for the study of its inhabitants' food supply. In this investigation we measured concentrations of total lipid and of the main storage lipid classes as long- and short-term indicators of the nutritional condition of Calanus euxinus females in different regions of the southern Black Sea. 


\section{METHODS}

One survey was performed in both cyclonic and anticyclonic regions, towards the end of the summer period of stratification. At this time, mixing is minimal, the euphotic zone is depleted of nutrients, and the coupling between phytoplankton and its consumers becomes tighter (Coldman 1988).

Sampling was carried out at 6 stations in the southern Black Sea between 25 September and 4 October 1996 (on board the RV 'Bilim', Institute of Marine Sciences, Middle East Technical University, Turkey) (see Table 1, Fig. 1B). According to the research objective, 3 stations each were chosen in cyclonic and anticyclonic regions identified from the depth of $\sigma_{t}=16.2$ density value. It is known that this value corresponds to the lower boundary of the oxic layer and changes with respect to circulation direction (Vinogradov et al. 1992b, Saydam et al. 1993, Murray et al. 1995). A $\sigma_{t}=$ 16.2 value at a depth of 100 to $120 \mathrm{~m}$ is indicative of the cyclonic circulation, and at a depth of 160 to $200 \mathrm{~m}$ indicates the anticyclonic circulation. It should be noted that $\operatorname{Stn} 4$ is not in the centre but in the periphery of the anticylonic region.

Basic oceanographic parameters, such as temperature $\left({ }^{\circ} \mathrm{C}\right)$, salinity $(\% \circ)$, and chlorophyll in situ fluorescence, of the water column were measured using a Sea Bird CTD probe. Water samples for nutrient analyses were collected with a Rosette sampler attached to the CTD. Nitrate $\left(\mathrm{NO}_{3}\right)$ and phosphate $\left(\mathrm{PO}_{4}\right)$ concentrations were measured using standard methods (Graßhoff et al. 1983). Chl a concentrations were measured from 5 to 7 depths (chosen according to in situ fluorescence profiles) in the 0 to $75 \mathrm{~m}$ layer, using the fluorometric method on acetone extracts (JGOFS Protocols 1994). The lower boundary of the chl a containing layer was estimated from the chlorophyll fluorescence in situ minimum. Profiles of chl a, $\mathrm{NO}_{3}$ and $\mathrm{PO}_{4}$ were drawn, and mean integrated concentrations for this layer evaluated.

During the survey, Calanus euxinus were caught using a Nansen plankton net $(112 \mu \mathrm{m}$ mesh size, $0.7 \mathrm{~m}$ diameter) at night (21:00 to 01:30 h) in surface waters (from 30-50 to $0 \mathrm{~m}$ ). It is known that during these hours late stages of $C$. euxinus ascend from deeper waters towards the sea surface to feed (Petipa 1965, Besiktepe et al. 1998). It was easy to understand the feeding activity from microscopic observations of micro-algal remains in the guts of copepods. It turned out that almost all females caught ate well, whereas Stage $V$ copepodites had empty (or not full) stomachs (average $80 \%$ ). Therefore, only the former group was used for the evaluation of $C$. euxinus food supply.

Two replicates comprising approximately 50 Calanus euxinus females each were used for lipid determi- nations. The size (prosome length) of females used in analyses ranged from 3.3 to $3.5 \mathrm{~mm}$ and their calculated wet weight (Svetlichny 1983) was 1012 to $1077 \mu \mathrm{g}$ ind. ${ }^{-1}$. Copepods were removed from the water and immediately put in a chloroform-methanol $(2: 1, \mathrm{v} / \mathrm{v})$ mixture for lipid extraction (Folch et al. 1957) without preliminary homogenisation. Ohman (1988) and Håkanson $(1987,1989)$ showed that the extraction efficiency of whole individuals without homogenisation was good for small organisms such as copepods or fish larvae (>98\% of lipids extracted). The samples were extracted twice during $24 \mathrm{~h}$ with the fluid transferred after each $24 \mathrm{~h}$ period. The resulting extracts were stored at $-20^{\circ} \mathrm{C}$ for no more than $2 \mathrm{wk}$. These were used for further qualitative and quantitative determinations of lipid content in the laboratory. The sulfovanillin technique (Barnes \& Blackstock 1973) was applied to define the content of total lipid in extracts. Lipids, extracted from $C$. euxinus, vacuum dried and weighted on a Cahn electrobalance according to Kates (1975), were used as a standard for calibration.

The lipid was fractionated by unidimensional thinlayer chromatography on $5 \times 15 \mathrm{~cm}$ Silufoll UW254 plates (Kavalier Ltd, Czech Republic) using solvents of different polarity in special arrangement of the chromatography chamber ( 3 cylindrical chambers of different size were nestled in each other) as described by Kopitov (1983). The outer large chamber (diameter $15 \mathrm{~cm}$ and height $21 \mathrm{~cm}$ ) was preliminarily saturated for $2 \mathrm{~h}$ with hexane; the intermediate chamber (diameter $7 \mathrm{~cm}$, height $13.5 \mathrm{~cm}$ ) was saturated with a hexanediethyl ether $(9: 1 \mathrm{v} / \mathrm{v})$ mixture; the small innermost chamber (diameter $5.5 \mathrm{~cm}$, height $1.0 \mathrm{~cm}$ ) contained chloroform.

Plates were activated at $105^{\circ} \mathrm{C}$ for 30 min and treated with a $10 \%$ solution of phosphomolibdenum acid in ethanol before the chromatography procedure. A 20 to $50 \mu \mathrm{g}$ sample of lipid was applied to each plate under nitrogen. All chambers were quickly assembled inside in each other and the plate was immediately put into the innermost chamber. Thus, the plate was developed in solvents with decreasing polarity for $10 \mathrm{~min}$. Chromatograms were visualised by heating at $110^{\circ} \mathrm{C}$ for 7 min and quantified densitometrically, using an ERS densitometer (Karl Zeiss, Germany). The lipid classes (phospholipids: PL, sterol: S, free fatty acids: FFA, triacylglycerols: TAG, and wax esters: WE) were identified against a suite of lipid standards (Sigma Chemical Co.). Contents of total lipid (TL) and lipid classes were given as $\mu \mathrm{g}$ ind. ${ }^{-1}$.

Along with Calanus euxinus sampled from surface waters, mesozooplankton was taken from throughout the entire aerobic layer in vertical hauls with the same Nansen plankton net. Samples were treated with 

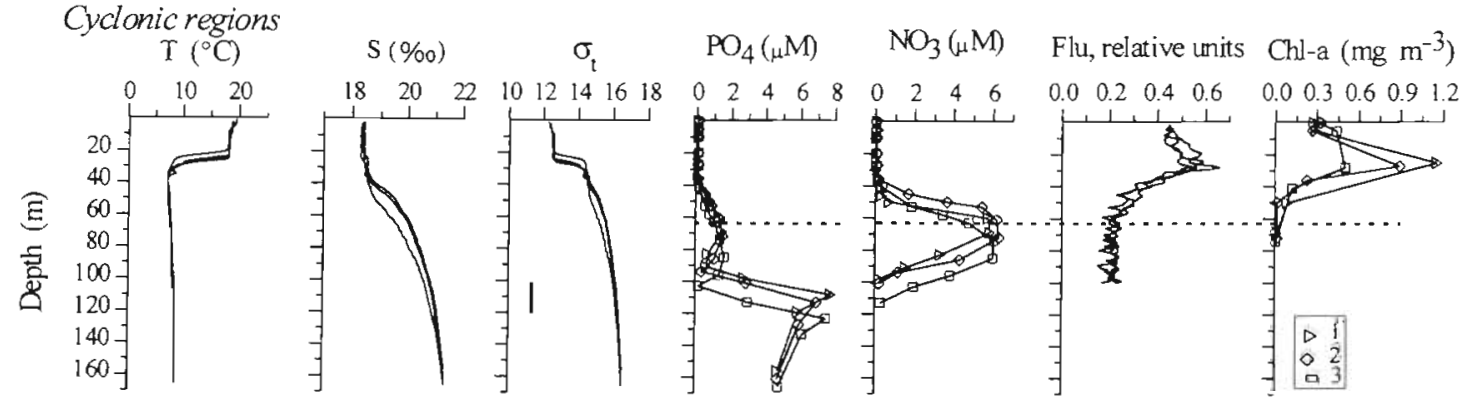

Anticyclonic regions
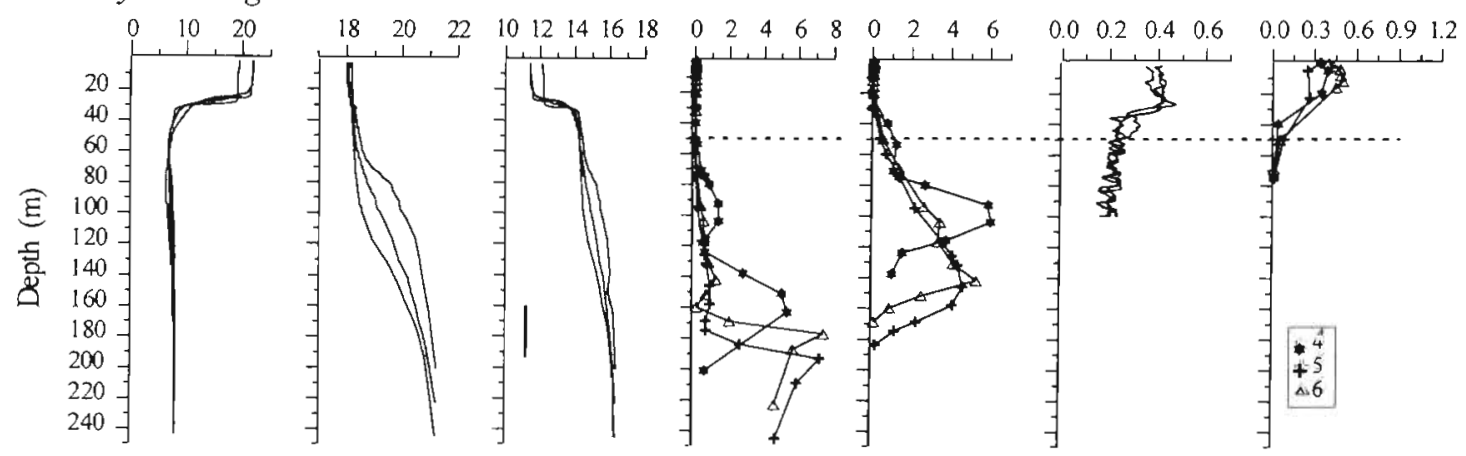

Fig. 2. Vertical profiles of temperature $\left(\mathrm{T},{ }^{\circ} \mathrm{C}\right)$, salinity $(\mathrm{S}, \%)$, density $\left(\sigma_{\mathrm{t}}\right)$, phosphate $\left(\mathrm{PO}_{4}\right)$, nitrate $\left(\mathrm{NO}_{3}\right)$, chl a in situ fluorescence (FLU) and chl a concentrations from cyclonic (Stns 1, 2 and 3) and anticyclonic regions (Stns 4, 5 and 6). Bold line on $\sigma_{t}$ profiles shows the lower border of the oxic zone identified as the 16.2 density value. Dashed lines indicate the lower border of the chl a containing layer

buffer solutions of formaldehyde, and enumeration, species identification and size measurements were carried out under a binocular microscope using a Bogorov chamber. The biomass of individual organisms was evaluated by the computation technique as described by Petipa (1957).

The hypothesis that the in situ lipid content of the copepod Calanus euxinus is a function of food supply was tested using Simple Linear Correlation analysis (Zar 1984).

\section{RESULTS}

The physical and chemical patterns of stations in cyclonic (the eastern and the western cyclonic gyres) and anticyclonic (Batumi and quasi-permanent Kizilirmak anticyclonic eddies) regions are shown in Table 1 and Fig. 2. The temperature profiles showed the presence of a quasi-homogeneous 'mixing' layer situated 15 to $20 \mathrm{~m}$ above the thermocline (maximum gradient 0.6 to $1.4^{\circ} \mathrm{C} \mathrm{m}^{-1}$ ). The maximum gradient of salinity

Table 1. Hydrophysical and hydrochemical patterns and chl a content at the stations from the cyclonic and anticyclonic regions. Temperature and salinity are given as the mean values in the upper quasi-homogeneous (temperature) 'mixed layer'; chl $a_{1} \mathrm{NO}_{3}$ and $\mathrm{PO}_{4}$ are mean integrated concentrations for the chl a containing layer

\begin{tabular}{|c|c|c|c|c|c|c|c|c|}
\hline Stn & Coordinate & $\begin{array}{c}\text { Date (c.mo.yr); } \\
\text { time }\end{array}$ & $\begin{array}{c}\text { Temperature } \\
\left({ }^{\circ} \mathrm{C}\right)\end{array}$ & $\begin{array}{l}\text { Salinity } \\
(\% 0)\end{array}$ & $\begin{array}{c}\text { Depth }(\mathrm{m}) \\
\text { of } \sigma_{t}=16.2 \text { value }\end{array}$ & $\begin{array}{l}\mathrm{NO}_{3} \\
(\mu \mathrm{M})\end{array}$ & $\begin{array}{c}\mathrm{PO}_{4} \\
(\mu \mathrm{M})\end{array}$ & $\begin{array}{c}\text { Chl a } \\
\left(\mathrm{mg} \mathrm{m}^{-3}\right)\end{array}$ \\
\hline \multicolumn{9}{|c|}{ Cyclonic regions } \\
\hline 1 & $42^{\circ} 50 \mathrm{~N}, 31^{\circ} 15 \mathrm{E}$ & $26.9 .96 ; 23: 00 \mathrm{~h}$ & 18.47 & 18.29 & 105 & 1.326 & 0.423 & 0.49 \\
\hline 2 & $42^{\circ} 50 \mathrm{~N}, 33^{\circ} 30 \mathrm{E}$ & $27.9 .96 ; 21: 00 \mathrm{~h}$ & 18.88 & 18.41 & 113 & 0.871 & 0.275 & 0.35 \\
\hline 3 & $42^{\circ} 50 \mathrm{~N}, 37^{\circ} 15 \mathrm{E}$ & $2.10 .96 ; 21: 00 \mathrm{~h}$ & 18.55 & 18.35 & 123 & 0.790 & 0.200 & 0.29 \\
\hline Mean & & & 18.63 & 18.35 & 114 & 0.996 & 0.299 & 0.38 \\
\hline \multicolumn{9}{|c|}{ Anticyclonic regions } \\
\hline 4 & $42^{\circ} 10 \mathrm{~N}, 36^{\circ} 15 \mathrm{E}$ & $2.10 .96 ; 01: 30 \mathrm{~h}$ & 19.20 & 18.24 & 160 & 0.532 & 0.109 & 0.21 \\
\hline 5 & $41^{\circ} 50 \mathrm{~N}, 39^{\circ} 45 \mathrm{E}$ & $3.10 .96 ; 22: 00 \mathrm{~h}$ & 21.61 & 18.08 & 193 & 0.371 & 0.032 & 0.19 \\
\hline 6 & $41^{\circ} 30 \mathrm{~N}, 39^{\circ} 45 \mathrm{E}$ & $4.10 .96 ; 22: 00 \mathrm{~h}$ & 21.72 & 18.01 & 180 & 0.412 & 0.042 & 0.23 \\
\hline Mean & & & 20.80 & 18.11 & 178 & 0.438 & 0.061 & 0.21 \\
\hline
\end{tabular}


$\left(0.056\right.$ to $\left.0.080 \% \mathrm{~m}^{-1}\right)$ in cyclonic regions was observed at a depth of 40 to $50 \mathrm{~m}$, and in anticyclonic regions at 60 to $120 \mathrm{~m}$. In cyclonic regions the $\sigma_{t}=16.2$ value, indicating the lower boundary of the oxic layer, was located at a depth of 105 to $123 \mathrm{~m}$, and in the anticyclonic regions at a depth of 160 to $193 \mathrm{~m}$.

The lower boundary of the chl a containing layer (according to minimum values obtained from the fluorescence profiles) was located at 60 to $65 \mathrm{~m}$ in cyclonic regions and at 45 to $50 \mathrm{~m}$ in anticyclonic regions. Low phosphate $(0.04$ to $0.05 \mu \mathrm{M})$ and nitrate concentrations $(0.02$ to $0.06 \mu \mathrm{M})$ were observed down to a depth of 25 to $35 \mathrm{~m}$ in cyclonic regions, and down to 50 to $60 \mathrm{~m}$ in anticyclonic regions. Thus, mean integrated concentrations of $\mathrm{PO}_{4}$ and $\mathrm{NO}_{3}$ within the chl a containing layer were 4.9- and 2.3-fold higher, respectively, in cyclonic than in anticyclonic regions (Table 1). Similarly, chl a concentrations (as an indication of phytoplankton biomass) in cyclonic regions were on average twice as high as in anticyclonic areas. There were negative correlations between the depth of $\sigma_{t}=16.2$ value versus concentrations (mean integrated) of $\mathrm{PO}_{4}(\mathrm{r}=-0.93, \mathrm{p}<$ $0.005)$ and $\mathrm{NO}_{3}(\mathrm{r}=-0.91, \mathrm{p}<0.005)$ and positive correlations between chl a versus $\mathrm{PO}_{4}(\mathrm{r}=0.94, \mathrm{p}<0.005)$ and $\mathrm{NO}_{3}(\mathrm{r}=0.95, \mathrm{p}<0.005$ ) concentrations (Fig. 3).

The total mesozooplankton biomass did not differ notably between the 2 different regions, and on average was $2775 \mathrm{mg} \mathrm{m}^{-2}$ (Table 2). In both regions about $20 \%$ of the total biomass was accounted for by small copepods (e.g. Acartia clausi, Paracalanus parvus, Pseudocalanus elongatus and Oithona similis) and other mesozooplankton species (e.g. Sagitta setosa, Oikopleura diocica, molluscs and polychaete larvae). The remainder (approx. $80 \%$ ) of the mesozooplankton biomass consisted of 2 species - the copepod Calanus
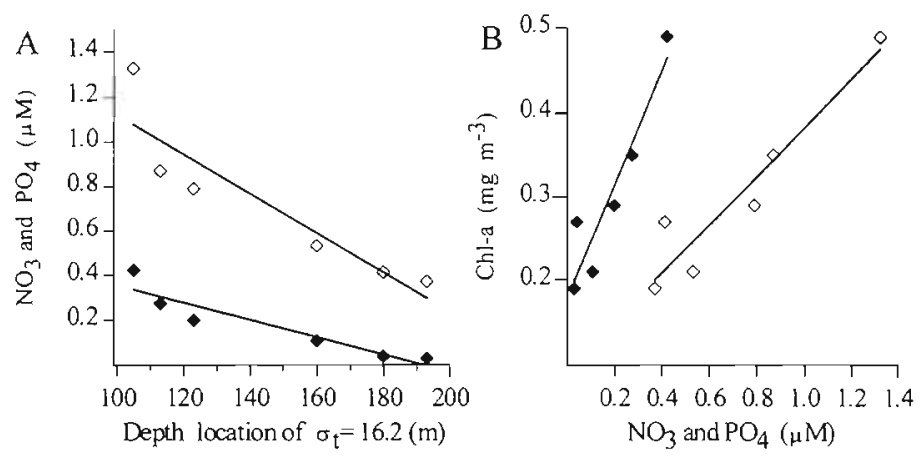

Fig. 3. Relationships of (A) depth (m) of the $\sigma_{1}=16.2$ value versus mean integrated concentrations of nitrates $\left(\mathrm{NO}_{3}\right)$ and phosphates $\left(\mathrm{PO}_{4}\right)(\mathrm{r}=-0.91, \mathrm{p}<0.005$ and $\mathrm{r}=-0.93, \mathrm{p}<0.005$, respectively $)$, and (B) mean integrated concentrations of $\mathrm{chl}$ a versus nitrate $(\mathrm{r}=0.95$, $\mathrm{p}<0.005)$ and phosphate $(\mathrm{r}=0.94, \mathrm{p}<0.005) .(\diamond)$ Nitrates, $(\bullet)$ phosphates

euxinus and the heterotrophic dinoflagellate Noctiluca miliaris. The biomass of $C$. euxinus in cyclonic regions was on average 3.5 -fold greater than that of $N$. miliaris, but in anticyclonic regions they were present in similar proportions. The relationship between the chl a concentration and the $C$. euxinus and $N$. miliaris biomasses was also different: there was no relation to the biomass of $C$. euxinus $(r=0.4, p>0.2)$, but the chl a concentration was negatively correlated with $N$. miliaris $(\mathrm{r}=-0.73, \mathrm{p}<0.05)$.

Females constituted on average $24 \%$ of total abundance of the Calanus euxinus population (Table 3 ). The number of females was significantly higher than that of males, with ratios of 30:1 and 6:1 in cyclonic and anticyclonic regions, respectively. The number of $C$. euxinus eggs in the net hauls was similar between the 2 regions and was on average 8537 eggs $\mathrm{m}^{-2}$. Stage $\mathrm{V}$ copepodites were always the dominating group (>50\% of total $C$. euxinus abundance). The combined abun-

Table 2. Biomass (wet weight) of the main species of mesozooplankton from cyclonic and anticyclonic regions. \% $\%$ as a percent age of total mesozooplankton biomass

\begin{tabular}{|c|c|c|c|c|c|c|c|}
\hline Stn & \multicolumn{2}{|c|}{$\begin{array}{l}\text { Calanus euxinus } \\
\left(\mathrm{mg} \mathrm{m}^{-2}\right)\end{array}$} & \multicolumn{2}{|c|}{$\begin{array}{c}\text { Calanoidea } \\
\text { and other species } \\
\left(\mathrm{mg} \mathrm{m}^{-2}\right)\end{array}$} & $\begin{array}{r}\text { Noctilue } \\
\left(\mathrm{mg} \mathrm{m}^{-2}\right)\end{array}$ & $\begin{array}{l}\text { iaris } \\
(\%)\end{array}$ & $\begin{array}{l}\text { Total biomass } \\
\qquad\left(\mathrm{mg} \mathrm{m}^{-2}\right)\end{array}$ \\
\hline \multicolumn{8}{|c|}{ Cyclonic regions } \\
\hline 1 & 1454 & 68 & 410 & 19 & 260 & 12 & 2124 \\
\hline 2 & 2283 & 59 & 788 & 20 & 768 & 20 & 3839 \\
\hline 3 & 970 & 66 & 266 & 18 & 239 & 16 & 1475 \\
\hline Mean & 1569 & 64 & 488 & 19 & 422 & 17 & 2479 \\
\hline \multicolumn{8}{|c|}{ Anticyclonic regions } \\
\hline 4 & 1430 & 40 & 459 & 12 & 1780 & 48 & 3669 \\
\hline 5 & 1030 & 38 & 449 & 17 & 1188 & 44 & 2667 \\
\hline 6 & 1070 & 37 & 896 & 31 & 908 & 32 & 2874 \\
\hline Mean & 1177 & 38 & 601 & 20 & 1292 & 41 & 3070 \\
\hline
\end{tabular}


Table 3. Abundance (ind. $\mathrm{m}^{-2}$ ) of different Calanus euxinus stages from cyclonic and anticyclonic regions. $\mathrm{N}=n \mathrm{naplii} ; \mathrm{C}=$ copepodites

\begin{tabular}{|c|c|c|c|c|c|c|c|c|c|c|}
\hline $\operatorname{Stn}$ & Eggs & NV & NVI & $\mathrm{CI}$ & CII & CIII & CIV & $\mathrm{CV}$ & Female & Male \\
\hline \multicolumn{11}{|c|}{ Cyclonic regions } \\
\hline 1 & 4160 & 387.4 & 65 & 83.2 & 41.6 & 20.8 & 13.0 & 1136.2 & 473.2 & 31.2 \\
\hline 2 & 9620 & 124.8 & 312 & 44.2 & 31.2 & 0 & 0 & 1991.6 & 647.4 & 10.4 \\
\hline 3 & 12220 & 161.2 & 0 & 26 & 0 & 41.6 & 31.2 & 618.8 & 403.0 & 10.4 \\
\hline Mean & 8667 & 224.5 & 125.7 & 51.13 & 24.27 & 20.8 & 14.7 & 1248.9 & 507.9 & 17.3 \\
\hline \multicolumn{11}{|c|}{ Anticyclonic regions } \\
\hline 4 & 7410 & 166.4 & 62.4 & 88.4 & 13.0 & 65 & 161.2 & 1034.8 & 452.4 & 52.0 \\
\hline 5 & 8190 & 1690 & 0 & 0 & 0 & 10.4 & 10.4 & 410.8 & 543.4 & 83.2 \\
\hline 6 & 9620 & 0 & 0 & 10.4 & 0 & 10.4 & 156 & 954.2 & 189.8 & 62.4 \\
\hline Mean & 8407 & 619 & 20.8 & 32.9 & 4.33 & 28.6 & 109.2 & 780 & 395 & 66.0 \\
\hline
\end{tabular}

dances of Stages I to IV copepodites was 5.5- to 12.2fold less than Stage V copepodites.

Contents of TL and of the main lipid classes of Calanus euxinus females are shown in Fig. 4. TL concentrations from the cyclonic regions were on average 1.7 -fold greater than in anticyclonic regions (101.9 and $58.8 \mathrm{\mu g}$ ind $^{-1}$, respectively). A similar difference between the 2 regions was also shown for WE which make up 70 to $72 \%$ of TL. Concentrations of TAG 18 to $13 \%$ of TL), PL (13 to $15 \%)$ and S ( 3 to $5 \%$ ) of C. euxinus females sampled from cyclonic regions were higher than those from anticyclonic areas. The level of $C$. euxinus TL responded to differences in chl a concentration ( $r=0.95, p<0.005$; Fig. 5). Chl a also correlated well with WE contents $(r=0.89, p<0.05)$. Neither TAG nor PL correlated with chl $a$, but both displayed

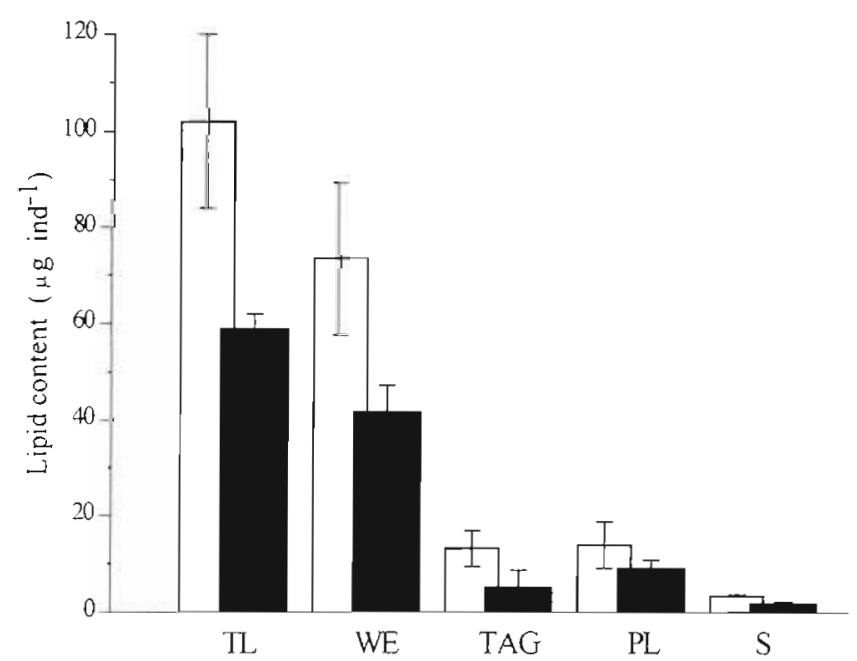

Fig. 4. Average content of total lipids (TL) and main lipid classes of Calanus euxinus females from cyclonic (open bars) and anticyclonic (dark bars) regions. WE $=$ wax esters, $\mathrm{TAG}=$ triacylglycerols, $\mathrm{PL}=$ phospholipids, $\mathrm{S}=$ sterols. Error bars show 1 standard deviation positive trends ( $r=0.71, p<0.2$ and $r=0.61, p<0.2$, respectively).

\section{DISCUSSION}

In the Black Sea, density stratification of the upper layer in summer prevents the penetration of the bottom layers, which are rich in nutrients, into the surface waters. Nutrients transported from deeper waters by conventional winter 'mixing' are completely consumed during the winter-spring phytoplankton bloom. In fact, in 1996 the spring bloom was apparently over by May, when deep chlorophyll minima and low primary production rates were observed (Stelmakh et al. 1998, Yilmaz et al. 1998). In the open waters, phytoplankton growth in the post-bloom period is fuelled mainly by means of regenerated nutrients, and 'new' production can only occur if 'new' nutrients are brought from

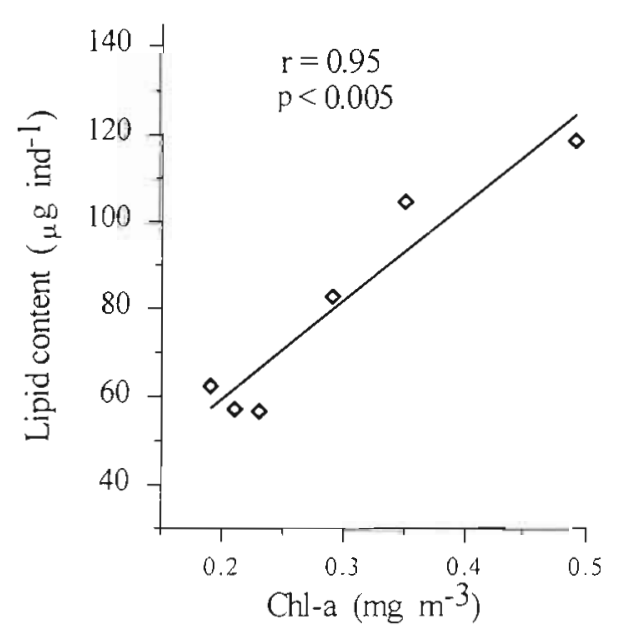

Fig. 5. Relationship of total lipid (TL) contents of Calanus euxinus females versus mean integrated concentrations of chl a 
depth up into the lower strata of the euphotic zone (Goldman 1988).

The penetration of nutrients into the chl a containing layer of the Black Sea during summer stratification occurs in regions of cyclonic circulation, where doming is found. In this study, the increase in nutrient concentration started at $40 \mathrm{~m}$, and the chl a containing layer extended down to 60 to $65 \mathrm{~m}$ within the cyclonic regions (Fig. 2). In contrast, the increase in nutrient concentration was not seen until 55 to $65 \mathrm{~m}$ in regions with anticyclonic circulation, i.e. only below the base of the chl a containing layer. In the present study, the close relationships found between depth of the $\sigma_{t}=16.2$ value and $\mathrm{NO}_{3}, \mathrm{PO}_{4}$ and chl a concentrations from both cyclonic and anticyclonic regions confirm the important role of hydrodynamics in ecosystem structure and productivity (Fig. 3). The higher phytoplankton biomass (deduced from both chl a and in situ fluorescence levels) in cyclonic regions (Table 1, Fig. 2) might indicate that the food of herbivorous zooplankton was more plentiful in this region.

Unlike phytoplankton, the total mesozooplankton biomass in the compared regions did not reveal striking differences. There were, however, considerable differences in the biomass ratios of the main species; i.e. the copepod Calanus euxinus versus the heterotrophic dinoflagellate Noctiluca miliaris. C. euxinus predominated in cyclonic regions, whereas in anticyclonic areas the biomass of $N$. miliaris was higher than that of $C$. euxinus (Table 2). The relationships between these 2 species and food supply (in terms of chl a) were also different: no relationship existed for the $C$. euxinus biomass, whereas a strong negative correlation was seen for $N$. miliaris.

In general, the biomass of zooplankton alone is considered to be a poor indicator of their nutritional condition and productivity (Raymont 1976, Parsons et al. 1984). In our case, one of the reasons for the lack of correlation between the Calanus euxinus biomass and chl a might be due to heavy predation on copepods by ctenophora (Pleurobrachia rhodopis and Mnemiopsis leidyi), medusae and planktivorous fishes (Anninsky et al. 1998, Kovalev et al. 1998). However, the strong correlation between the biomass of Noctiluca miliaris and chl a may testify that, in contrast to $C$. euxinus, predators did not exert significant feeding pressure on $N$. miliaris. Indeed this dinoflagellate has no known predators in the Black Sea. At the same time it is known that the $N$. miliaris food ration may include copepod and fish eggs (Mironov 1954, Elbrächter \& Qi 1998). But in our investigations we seldom observed eggs in the food vacuoles of $N$. miliaris, in which microalgal remains prevailed.

It is likely that in the Black Sea Noctiluca miliaris and Calanus euxinus can be considered as food competi- tors. Both species appear to feed effectively on phytoplankton during night-time in surface waters, and diatoms are their preferred food items (Mironov 1954 Petipa 1965, 1981, Besiktepe et al. 1998, Elbrächter \& Qi 1998). However, unlike $C$. euxinus, $N$. miliaris is able to grow and reproduce whilst feeding on smaller sizes of phytoplankton (5 to $25 \mu \mathrm{m}$ ) at a much lower food concentration (Mironov 1954, Petipa 1981 , Elbrächter \& Qi 1998). In our case such an ability might allow $N$. miliaris to avoid competitive pressure from $C$. euxinus in anticyclonic regions of low food abundance. It is worth noting that the biomass of $N$. miliaris increased from $422 \mathrm{mg} \mathrm{m}^{-2}$ in cyclonic regions to $1292 \mathrm{mg} \mathrm{m}^{-2}$ in anticyclonic regions (Table 2).

During the survey in September 1996 Stage V copepodites and females dominated the Calanus euxinus population (56 and $24 \%$ of total numbers, respectively) in both compared regions (Table 3). Besiktepe et al. (1998) found that over $95 \%$ of females made daily vertical migrations to feed in September. The presence of eggs in the net hauls testified that $C$. euxinus females had spawned and the relatively small numbers of nauplii and Stage I to III copepodites (Table 3) indicated, apparently, that the females had only begun to reproduce, no more than $1 \mathrm{wk}$ earlier (Sazhina 1987).

Contents of TL (and their main classes, WE, PL, TAG and S) of actively feeding Calanus euxinus females reacted to variations in phytoplankton abundance (in terms of chl a) between the compared regions (Fig. 4). All lipid contents were higher in cyclonic regions. A significant correlation with chl a was found for TL ( $\mathrm{r}=$ 0.95, $p<0.005$; Fig. 5$)$ and WE $(r=0.85 ; p<0.05)$ contents, which account for most of the TL (over $70 \%$; Fig. 4). The correlation between TAG (8 to $13 \%$ of TL) and chl a was not significant ( $\mathrm{r}=0.71, \mathrm{p}<0.2)$ (Fig. 5). In June 1991 a close relationship between the chl $a$ and lipid contents was found not only for female C. euxinus, but also for the feeding Stage $V$ copepodites (Yuneva et al. 1997). Correlation coefficients between WE and chl a were high for both Stage $V$ copepodites and females $(r=0.90$ and 0.85 , respectively, $p<0.005)$, whereas those between TAG and chl a were not ( $\mathrm{r}=$ 0.62 and 0.53 , respectively, $p>0.2$ ). Similar results were obtained for WE and TAG contents of C.pacificus in their correlation with primary production (Håkanson 1987).

It has been shown that calanoid copepods have a marked propensity to convert their largely phytoplankton diet into WE, and WE content is the longterm indicator for the nutritional condition of many species of the genus Calanus (see review by Sargent \& Henderson 1986). C. euxinus and the closely related $C$. pacificus and $C$. helgolandicus start to synthesise WE during at copepodite Stages III to IV (Lee et al. 1972, Håkanson 1984, Yuneva unpubl, data) reaching 
a maximum at the Stage V copepodite (Lee et al. 1972, Håkanson 1984, Yuneva et al. 1997). In the laboratory, the duration of copepodite Stages IV and V of C. euxinus before becoming adult averages 2 wk (Sazhina 1987). The level of WE accumulation during these stages depends on the animal's food supply (Sargent et al. 1977. Håkanson 1984). Before moulting into females, Stage $V$ copepodites of $C$. euxinus, as a rule, diapause for some time (exact time unknown) in the suboxic zone (Vinogradov et al. 1992a). During this period some of the energy derived from the stored WE may be invested for the development of gonads which will eventually be spent at spawning (Gatten et al. 1980, Sargent \& Henderson 1986, Sargent \& FalkPeterson 1988). So, whereas the WE content of feeding Stage V copepodites reflects its feeding history, that of females may not, because of mobilization processes. In our investigation the level of WE mobilization of C. euxinus females was insignificant, because reproduction had only begun (deduced from the low number of early copepodite stages, Table 3), allowing us to obtain a close correlation between the chl a concentration and WE content. Therefore it is very likely that WE levels reflected differences in the nutritional condition of $C$. euxinus females in cyclonic and anticyclonic regions for at least several weeks prior to sampling.

Unlike WE, the TAG content may be considered as a measure of the immediate nutritional history of copepods over a period of several days (Sargent et al. 1977, Håkanson 1984). There are 2 main sources of TAG in Calanus spp. (Sargent \& Henderson 1986). The first one is lipid contained in their food and, therefore, various factors, such as duration of feeding, ensembles of consumed phytoplankton, omnivorous feeding, etc., may influence TAG content. WEs, when they are modified to gonads (Gatten et al. 1980, Arashkevitch et al. 1998), are the second source of TAG which is the stor-

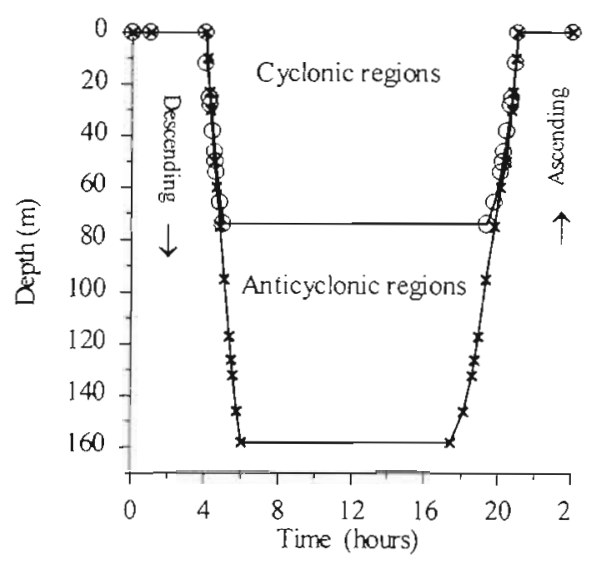

Fig. 6. Diurnal vertical migration patterns of Calanus euxinus females in cyclonic $(O)$ and anticyclonic $(x)$ zones age lipid found in Calanus eggs (Lee et al. 1972, Sargent \& Henderson 1986, Sargent \& Falk-Peterson 1988). TAG is rapidly synthesised during Calanus feeding but it is also utilised quickly. Besides spawning, TAG is also spent during locomotion, especially if copepods are performing diurnal vertical migrations (Sargent \& Falk-Peterson 1988). Differences in energy expenditure during locomotion and variations in egg reproduction rates under changeable environmental conditions may account for the high variability seen in the TAG content of Calanus species in this and previous studies (Håkanson 1987, Yuneva et al. 1997) and consequently for the absence of a correlation with phytoplankton abundance.

The daily energy expenditure of copepods may influence not only TAG, but also total lipid accumulation. If energy expenditure is high, a smaller portion of consumed food is used for lipid accumulation. For example, it has been suggested that low concentration of lipids in Calanus spp. in tropical regions may be linked not only with a poor food supply, but also with the energy cost of extensive vertical migration (Benson et al. 1972, Lee et al. 1972).

The depth of vertical migration of Calanus euxinus in the Black Sea depends on density stratification of water masses (Vinogradov et al. 1992a), and therefore it is different for cyclonic and anticyclonic regions. So during the summer stratification period $C$. euxinus females descend (after night feeding in warm and oxygen-enriched water) to deeper water with low temperature $\left(7\right.$ to $8^{\circ} \mathrm{C}$ ) and oxygen concentration $(0.3$ to $0.4 \mathrm{ml}$ $1^{-1}$ ) (Besiktepe et al. 1998). Water densities in these oxygen-depleted layers (= suboxic zone) are about $\sigma_{1}=$ 15.6 to 15.8 (Murray et al. 1995), corresponding to a depth of 65 to $84 \mathrm{~m}$ in cyclonic regions and to a depth of 120 to $158 \mathrm{~m}$ in anticyclonic regions (Fig. 2); thus the distance of vertical migrations of $C$. euxinus in anticyclonic areas is twice as far as that in cyclonic regions.

Using data from Besiktepe et al. (1998) on timing of ascent and descent of Calanus euxinus females from September 1995, we could depict diel vertical migration patterns for cyclonic and anticyclonic regions (Fig. 6). Apparently not only the distance of migration. but also the timing of descent and ascent as well. as the duration spent at depth differs to a certain degree for copepods from different regions. All these variables may affect its total daily expenditure.

Measurements of basal and active metabolism, in terms of oxygen consumption rates, made under different temperature and oxygen concentrations for Calanus euxinus females have been reported elsewhere (Svetlichny \& Gubareva 1998). Combining this data with temperature (Fig. 2) and oxygen concentration profiles typical for cyclonic and anticyclonic regions (Bastürk et al. 1994), Svetlichny et al. (unpubl. data) 
discovered that daily energy expenditure of $C$. euxinus females varied from 18.6 to $21.0 \mu \mathrm{g} \mathrm{O}_{2} \mathrm{mg}^{-1}$ wet weight in cyclonic and anticyclonic regions, respectively. So the differences in the daily energy expenditure between the 2 regions were not large $(<12 \%)$ and would not be expected to greatly affect the level of food assimilation by copepods

Thus differences in the accumulation of lipid reserves in Calanus euxinus in cyclonic and anticyclonic regions of the Black Sea are largely due to variations in the levels of phytoplankton food in the 2 areas. These, in turn, can be attributed to differences in the hydrodynamics and supply of nutrients to the chl $a$ containing layer.

Acknowledgements. This work was supported by the Turkish Scientific and Technical Research Council (TUBITAK), and by a Linkage Grant (ENVIR.LG.973262) from NATO. We thank the crew of the RV 'Bilim' for assistance at sea and Mrs Alison Kideys for correcting the English of the text.

\section{LITERATURE CITED}

Anninsky BE, Romanova ZA, Abolmasova GI, Gücü AC, Kideys AE (1998) Ecological and physiological state of the ctenophore Mnemiopsis leidyi (Agassiz) in the Black Sea in autumn 1996. In: Ivanov LI. Özoy E (eds) NATO TU-Black Sea Project, ecosystem modeling as a management tool for the Black Sea, symposium on scientific results, Vol 1. Kluwer Academic Publishers, Dordrecht, p 249-262

Arashkevich EG, Svetlichny LS, Gubareva ES, Besiktepe S, Gücü AC, Kideys AE (1998) Physiological and ecological studies of Calanus euxinus (Hulsemann) from the Black Sea with comments on its life cycle. In: Ivanov LI, Özoy E (eds) NATO TU-Black Sea Project, ecosystem modeling as a management tool for the Black Sea, symposium on scientific results, Vol 1. Kluwer Academic Publishers, Dordrecht, p 351-366

Båmstedt U, Ervik A (1984) Local variations in size and activity among Calanus finmarchicus and Metridia longa (Copepods, Calanoida) overwintering on the west coast of Norway. J Plankton Res 6:843-857

Båmstedt U, Håkanson JL, Brenner-Larsen J, Bjoernsen PK, Geertz-Hansen O, Tiselius P (1990) Copepod nutritional condition and pelagic production during autumn in Kosterfjorden, western Sweden. Mar Biol 104:197-208

Barnes H, Blackstock J (1973) Estimation of lipids in marine animals and tissues: detailed investigation of the sulphophosvanillin method for total lipids. J Exp Mar Biol Ecol 1: $103-118$

Bastürk O, Saydam C, Salihoglu I, Eremeeva LV, Konovalov SK, Stoyanov A, Dimitrov A, Cociasu A, Dorogan L, Altabet $M$ (1994) Vertical variations in the principle chemical properties of the Black Sea in the autumn of 1991. Mar Chem 45:149-165

Bautista B, Harris RP, Tranter PRG, Harbour D (1992) In situ copepod feeding and grazing rates during a spring bloom dominated by Phaeocystis sp. in the English Channel. J Plankton Res 14:691-703

Benson AA, Lee RF, Nevenzel JC (1972) Wax esters: major marine metabolic energy sources. Biochem Soc Symp 35: $175-187$
Besiktepe S, Unsal M, Kideys AE (1998) In situ grazing rate and diel vertical migration of female Calanus euxinus in the Black Sea. Hydrobiologia 363:323-332

Cox JL, Willason S, Harding L (1983) Consequences of distributional heterogeneity of Calanus pacificus grazing. Bull Mar Sci 33:213-226

Dagg M (1977) Some effects of patchy food environment on copepods. Limnol Oceanogr 22:99-107

Elbrächter M, Qi YZ (1998) Aspects of Noctiluca (Dinophyceae) population dynamics. In: Anderson DM. Cembella AD, Hallegraeff GM (eds) Physiological ecology of harmful algal blooms. Springer-Verlag, Berlin, p 315-335

Fessenden L, Cowles TJ (1994) Copepod predation on phagotrophic ciliates in Oregon coastal waters. Mar Ecol Prog Ser 107:103-111

Folch J, Lees M, Sloane-Stanley GH (1957) A simple method for the isolation and purification of total lipids from animal tissues. J Biol Chem 226:497-509

Gatten RR, Corner EDS, Kilvington CC, Sargent JR (1979) A seasonal survey of lipids in Calanus helgolandicus Claus from the English Channel. In: Naylor E, Hartnoll RG (eds) Cyclic phenomena in marine plants and animals. Proceedings of the 13th European Marine Biology Symposium. Pergamon Press, Oxford, p 275-284

Gatten RR, Sargent JR, Forsberg TEV, O'Hara SCM, Corner EDS (1980) On the nutrition and metabolism of zooplankton. XIV. Utilization of lipid by Calanus helgolandicus during maturation and reproduction. J Mar Biol Assoc UK 60: 391-399

Goldman JC (1988) Spatial and temporal discontinuities of biological processes in pelagic surface waters. In: Rothschild BJ (ed) Toward a theory on biological-physical interactions in the world ocean. Kluwer Academic Publishers, Dordrecht, p 273-296

Graßhoff K, Ehrhard M, Kremling K (1983) Determination of nutrients. In: Methods of seawater analysis, 2nd edn. Verlag Chemie, Weinheim, Prepared and published jointly by American Public Health Ass.; American Water Works Ass., Water pollution control Federation, p 125-188

Håkanson JL (1984) The long and short term feeding condition in field-caught Calanus pacificus as determined from the lipid content. Limnol Oceanogr 29:794-804

Hâkanson JL (1987) The feeding condition of Calanus pacificus and other zooplankton in relation to phytoplankton pigments in the California Current. Limnol Oceanogr 32: $881-894$

Håkanson JL (1989) Analysis of lipid components for determining the condition of anchovy larvae, Engraulis mordax. Mar Biol 102:143-151

Hayward TL (1980) Spatial and temporal feeding patterns of copepods from the North Pacific central gyre. Mar Biol 58: $295-309$

Hirche HJ, Baumann MEM, Kattner G, Gradinger R (1991) Plankton distribution and the impact of copepod grazing on primary production in Fram Strait, Greenland Sea. J Mar Syst 2:477-494

JGOFS Protocols (1994) Protocols for the Joint Global Ocean Flux Study (JGOFS) Core Measurements, Manual and Guides. UNESCO 29:97-100

Kates M (1975) Techniques of lipidology. Mir Publishing, Moscow (translated into Russian)

Kopitov YuP (1983) New version of thin-layer chromatography of lipids. Ekol Morya 12:76-80 (in Russian)

Kovalev AV, Niermann U, Melnikov VV, Belokopytov V, Uysal Z, Kideys AE, Unsal M, Altukhov D (1998) Longterm changes in the Black Sea zooplankton: the role of 
natural and anthropogenic factors. In: Ivanov LI, Özoy E (eds) NATO TU-Black Sea Project, ecosystem modeling as a management tool for the Black Sea, symposium on scientific results, Vol 1. Kluwer Academic Publishers, Dordrecht, p 221-234

Lee RF, Barnes AT (1975) Lipids in the mesopelagic copepod Gaussia princeps: wax ester utilization during starvation. Comp Biochem Physiol 52B:265-268

Lee RF, Nevenzel JC, Paffenhofer GA (1970) The metabolism of wax-esters and other lipids by the marine copepod Calanus helgolandicus. J Lipid Res 11:237-240

Lee RF, Nevenzel JC. Paffenhöfer GA (1971) Importance of wax esters and other lipids in the marine food chain: phytoplankton and copepods. Mar Biol 9:99-108

Lee RF, Hirota J, Nevenzel JC, Sauerheber R, Benson AA, Lewis A (1972) Lipids in the marine environment. Calif Mar Res Comm 16:95-102

Marshall SM, Orr AP (1972) The biology of a marine copepod. Springer-Verlag, Berlin

Mironov GN (1954) Feeding of plankton predators. I. Feeding of Noctiluca. Proc Sevastopol Biol Stat 8:320-340 (in Russian)

Mullin MM (1991) Production of eggs by the copepod Calanus pacificus in the southern California sector of the California Current System. Rep-CCOFI 32:65-90

Murray JW, Codispoti LA, Frederich GE (1995) Oxidation reduction environments: the suboxic zone in the Black Sea. In: Huang CP, O'Melia, CR, Morgan JJ (eds) Aquatic chemistry. Adv Chem Ser 244:157-176

Niermann U, Kideys AE, Kovalev AV, Melnikov VV, Belokopytov $V$ (1999) Fluctuations of pelagic species of the open Black Sea during 1980-1995 and possible teleconnections. In: Besiktepe S, Unluata U, Bologa AS (eds) Environmental degradation of the Black Sea: challenges and remedies, Vol 1. Kluwer Academic Publishers, Dordrecht, p 249-262

Oguz T, Latun VS, Latif MA, Vladimirov VV, Sur HI, Markov AA, Özsoy E, Kotovshchikov BB, Eremeev VV, Ünlüata U (1993) Circulation in the surface and intermediate layers of the Black Sea. Deep-Sea Res 40:1597-1612

Ohman MD (1988) Sources of variability in measurements of copepod lipids and gut fluorescence in the California Current coastal zone. Mar Ecol Prog Ser 42:143-153

Ohman MD, Runge JA (1994) Sustained fecundity when phytoplankton resources are in short supply: omnivory by Calanus finmarchicus in the Gulf of St. Lawrence. Limnol Oceanogr 39:21-36

Ota AY, Landry MR (1984) Nucleic acids as growth rate indicators for early developmental stages of Calanus pacificus Brodsky. J Exp Mar Biol Ecol 80:147-160

Parsons TR, Takahashi M, Hargrave B (1984) Biological oceanographic Processes, 3rd edn. Pergamon Press, Oxford

Peterson WT, Tiselius P, Kioerboe T (1991) Copepod egg production, moulting and growth rates, and secondary production, in the Skagerrak in August 1988. J Plankton Res 13:131-154

Petipa TS (1957) On the mean weight of main forms of Black Sea zooplankton. Proc Sevastopol Biol Stn 9:33-57 (in Russian)

Petipa TS (1965) Diurnal grazing on phytoplankton by the

Editorial responsibility: Otto Kinne (Editor),

Oldendorf/Luhe, Germany copepod Calanus helgolandicus in the Black Sea. Zool Zh 44:844-854 (in Russian)

Petipa TS (1981) The trophodynamics of copepods in the marine planktonic communities. Naukova Dumka, Kiev, p 242 (in Russian)

Raymont JG (1976) Plankton and productivity in the oceans. Pergamon Press, Oxford

Sargent JR, Falk-Peterson S (1988) The lipid biochemistry of calanoid copepods. In: Boxshall GA, Schminke HK (eds) Hydrobiologia, Vol 167/168. Kluwer Academic Publishers Dordrecht, p 101-114

Sargent JR, Henderson RJ (1986) Lipids. In: Corner EDS, O'Hara SCM (eds) The biological chemistry of marine copepods. Clarendon Press, Oxford, p 59-108

Sargent JR, Gatten RR, Corner EDS, Kilvington CC (1977) On the nutrition and metabolism of zooplankton. XI. Lipids in Calanus helgolandicus grazing Biddulphia sinesis. J Mar Biol Assoc UK 57:525-533

Saydam C, Tugrul S, Basturk O, Oguz I (1993) Identification of the oxic/anoxic interface by isopycnal surfaces in the Black Sea. Deep-Sea Res I 40:1405-1412

Sazhina LI (1.987) Reproduction, growth, productivity of marine copepods. Naukova Dumka, Kiev (in Russian)

Stelmakh LV, Yunev OA, Finenko ZZ, Vedernikov VI, Bologa A, Churilova TYu (1998) Peculiarities of seasonal variability of primary production in the Black Sea. In: Ivanov LI, Özoy E (eds) NATO TU-Black Sea Project, Ecosystem modeling as a management tool for the Black Sea, Symposium on scientific results, Vol 1. Kluwer Academic Publishers. Dordrecht, p 93-104

Svetlichny LS (1983) Calculation of planktonic copepod biomass by means of coefficients of proportionality between volume and linear dimensions of the body. Ekol Morya 15: $32-46$

Svetlichny LS, Gubareva ES (1998) The effect of hypoxia on metabolism and locomotion of Calanus euxinus (Copepoda, Crustacea). Rep Nat Acad Sci Ukraine 5:199-201

Vinogradov ME, Arashkevich EG, Ilchenko SV (1992a) The ecology of the Calanus ponticus population in the deeper layer of its concentration in the Black Sea. J Plankton Res $14: 447-458$

Vinogradov ME, Sapozhnikov VV, Shushkina EA (1992b) Ecosystem of the Black Sea. Science, Moscow (in Russian)

Willason SW, Favuzzi J, Cox JL (1993) Patchiness and nutritional condition of zooplankton in the California Current. Fish Bull 84:157-176

Yilmaz A, Yunev OA, Vedernikov VI, Moncheva S, Bologa AS, Cociasu A, Ediger D (1998) Unusual temporal variations in the spatial distribution of chlorophyll-a in the Black Sea during 1990-96. In: Ivanov LI, Orsoy E (eds) NATO TU-Black Sea Project, Ecosystem modeling as a management tool for the Black Sea, Symposium on scientific results, Vol 1. Kluwer Academic Publishers, Dordrecht, p $105-120$

Yuneva TV, Svetlichny LS, Yunev OA, Georgieva LV, Senichkina LG (1997) Spatial variability of Calanus euxinus lipid content in connection with chlorophyll concentration and phytoplankton biomass. Oceanology 37:672-678

Zar JH (1984) Biostatistical analysis, 2nd edn. Prentice-Hall Inc, Englewood Cliffs, NJ

Submitted: December 9, 1998; Accepted: June 16, 1999

Proofs received from author(s): November 2, 1999 